\title{
Bacterial Artificial Chromosome
}

National Cancer Institute

\section{Source}

National Cancer Institute. Bacterial Artificial Chromosome. NCI Thesaurus. Code C1860.

Based upon the natural F plasmid of E. coli. Inserts up to $300 \mathrm{~Kb}$ can be cloned and stably maintained as circular molecules. 